\title{
ANALIZA TISKOVNIH I INTERNETSKIH OBJAVA O LOBIRANJU U HRVATSKOJ
}

Dubravka SINČIĆ ĆORIĆ

Ekonomski fakultet, Zagreb

Ivan VUKOVIĆ

Hrvatsko društvo lobista, Zagreb

UDK: 328.184(497.5)"2009/2010":050

$328.184(497.5) " 2009 / 2010^{\prime \prime}: 004.738 .5$

050(497.5)"2009/2010":328.124

Prethodno priopćenje

Primljeno: 18. 1. 2011.

Cilj rada jest analizirati medijske objave o lobiranju u Hrvatskoj, kako bi se upozorilo na prevladavajuću intonaciju i važnost pojma u medijskim sadržajima. U tu je svrhu provedena kvantitativna analiza sadržaja tekstova koji su objavlieni u tisku i na internetskim portalima. Kao izvori analize odabrane su dnevne, tjedne i mjesečne novine te internetski portali. Ukupno je analizirano 512 objava od 1. 1. 2009. do 1. 7. 2010. Analizirani su cjeloviti članci, koii su u naslovu ili tekstu sadržavali riječi "lobiranie", "lobisti", "lobistički" i/ili "lobist". Analiza upućuje na dva opća zakliučka: (1) lobisti i lobistička struka medijski su zanimljivi, čemu govori u prilog velik broj medijskih sadržaja o lobiranju, kao i povećanje broja objava kroz vrijeme te (2) sadržaji o lobiranju vrlo su različito intonirani s obzirom na kategorije analize. Sadržaji u kojima je lobiranje glavni pojam dominantno su pozitivno intonirani, dok su sadržaji u kojima je lobiranje sporedan pojam ili se samo spominje dominantno negativno intonirani, bez obzira na to je li lobiranje analizirano iz političke ili poslovne perspektive.

Ključne riječi: lobiranje, analiza sadržaja, medijske objave

$\bowtie$ Dubravka Sinčić Ćorić, Sveučilište u Zagrebu, Ekonomski fakultet, Trg J. F. Kennedyja 6, 10000 Zagreb, Hrvatska. E-mail: dsincic@efzg.hr

\section{UVOD}

Lobiranje je međunarodna industrija koja zapošljava velik broj visokoobrazovanih stručnjaka koji lobiraju za potrebe poduzeća, organizacija, interesnih skupina ili vlada. Lobistički utje- 
DRUŠ. ISTRAŽ. ZAGREB GOD. 21 (2012) BR. 2 (116)

STR. 545-567

SINČIĆ ĆORIĆ, D. VUKOVIĆ, I.: ANALIZA TISKOVNIH... caj najvećih europskih poduzeća još se slabo prepoznaje, unatoč sve većem prihvaćanju lobiranja kao djelatnosti i u poslovnoj sferi i opće u javnosti. Vjerojatni uzroci ove situacije jesu činjenice da je Europska komisija objavila dobrovoljni registar lobista tek 2008. godine, kao i da čak $40 \%$ najvećih europskih poduzeća nije registrirano $u$ registru (Friends of the Earth Europe, 2010.), pa se njihovo lobističko djelovanje ne može procijeniti. Prema dostupnim, iako nepotpunim, informacijama, može se utvrditi da europska poduzeća u lobiranje ulažu od petsto tisuća do milijun i pol eura godišnje (podaci za 2008. godinu, Friends of the Earth Europe, 2010.), što lobiranje čini zanimljivom i perspektivnom industrijom.

Hrvatski se lobisti susreću sa sličnim izazovima pozicioniranja struke kao i njihovi kolege u svijetu. No dodatno se suočavaju i s percepcijom visoke razine korupcije $^{1}$ i manjka transparentnosti unutar zakonodavne i izvršne vlasti. Takvo okruženje ne djeluje povoljno na razvoj (ugled) lobističke djelatnosti. Štoviše, negativna iskustva s posredništvom u dobivanju poslova na uglavnom vladinu tržištu nabavki rezultirala su dominantno negativnom percepcijom lobiranja, koje se u općoj javnosti poistovjećuje s posredništvom.

Budući da se lobistička struka u Hrvatskoj očito razvija, kao i da se hrvatska poduzeća približavaju centru europskog odlučivanja, Bruxellesu, vidi se da se struka i profesionalci lobisti - moraju jasnije pozicionirati. U pozicioniranju struke u poslovnoj i općoj javnosti ulogu imaju razni dionici: lobisti, strukovno udruženje, vlada, opća javnost i mediji, pri čemu je uloga medija u pozicioniranju među općom javnosti jamačno ključna. Stoga je cilj rada istražiti i analizirati tiskovne i internetske objave o lobiranju u Hrvatskoj, kako bi se na temelju nalaza upozorilo na prevladavajuću intonaciju i važnost pojma u sadržajima koji se vežu uz pojam lobiranja.

\section{POJMOVNO ODREĐENJE LOBIRANJA}

Iako je lobiranje poznat i općeprihvaćen pojam na koji se ve-
ćina ljudi u svakodnevnom govoru poziva bez zabune (OECD,
2009.), s teorijskoga gledišta još uvijek nije postignut konsen-
zus oko njegove jedinstvene definicije. Jedan od razloga vje-
rojatno leži u činjenici da se lobiranje može promatrati iz raz-
nih perspektiva: kao funkcija odnosa s javnošću, kao funkci-
ja integrirane marketinške komunikacije, kao zasebna poslovna
funkcija i/ili kao komunikacijski proces. Lobističke aktivnosti,
nadalje, uključuju brojne elemente i aktivnosti koje nije jed-
nostavno svesti pod zajednički nazivnik. Zatim, lobiranje mo-
že imati za cilj utjecanje na razne razine vlasti (lokalna, držav-
na, regionalna, transnacionalna) ili na oblike vlasti (pravna, za-
konodavna, izvršna). Konačno, lobirati mogu korporativni lo-
bisti, ugovorni lobisti, neprofitni lobisti, stručnjaci za odnose


DRUŠ. ISTRAŽ. ZAGREB GOD. 21 (2012), BR. 2 (116)

STR. 545-567

SINČIĆ ĆORIĆ, D. VUKOVIĆ, I.: ANALIZA TISKOVNIH... s javnošću, pa čak i vlade s ciljem utjecanja na neku drugu vladu (OECD, 2009.). Iz svega navedenog može se zaključiti kako poteškoće u definiranju lobiranja proizlaze iz složenosti same djelatnosti.

Najstariju definiciju lobiranja ponudio je Lester Milbrath, definirajući lobiranje kao simulaciju i prijenos komunikacija određenoga pojedinca, osim građanina koji djeluje u svoje ime, usmjerenih prema donositelju odluka unutar vlade s nadom utjecanja na ishod odlučivanja (Milbrath, 1960.). Iako se lobiranje $\mathrm{u}$ današnjem suvremenom svijetu uvelike promijenilo, ova je definicija i danas aktualna, jer brojni autori definiraju lobiranje kao nastojanje javnih i/ili privatnih sudionika da legalnim putem utječu na zakonodavce ili ostale javne službenike i političare, vezano uz određena pitanja koja su za te sudionike od posebnog interesa (Hogla i Nilsson, 2006.). Predočena definicija sadrži neke od ključnih elemenata za pojašnjenje lobiranja, kao što su: utjecanje, zakonodavci, javni službenici, političari i posebni interesi za sudionike.

Cutlip i suradnici lobiranje smještaju u kontekst odnosa s javnošću, navodeći kako je ono "specijalizirani dio odnosa s javnošću kojemu je svrha uspostavljanje i održavanje odnosa s državnom vlasti, poglavito s ciljem utjecanja na donošenje zakona i propisa" (2003., 18). Tusinski Berg (2009.) priklanja se ovakvu shvaćanju, smatrajući da je lobiranje komunikacijski proces, sličan odnosima s javnošću, koji djeluje s ciljem uvjeravanja ciljne skupine, $u$ najčešćem slučaju donositelja odluka vezanih uz javne politike. Vining i sur. (2005.) dodatno poopćavaju shvaćanje lobiranja, ističući da su to svi pokušaji komunikacija informacija prema političkim sudionicima. Ovakav način definiranja lobiranja čini lobiranje kao pojam suvišnim, s obzirom na to da se prijenos informacija može svrstati pod aktivnosti odnosa s javnošću ili marketinške komunikacije. Neprimjerenost ovako neusredotočenoga shvaćanja lobiranja potkrepljuju i pristupi drugih autora.

Hillman i Hitt (1999.) objašnjavaju kako lobiranje nastoji utjecati na javne politike pružanjem specifičnih informacija dionicima javnih politika te da to može uključivati pružanje informacija o koristima i troškovima različitih ishoda, preispitivanje donesenih odluka i njihovih ishoda ili stvaranje uvjeta za raspravu kanaliziranu u željenom smjeru. Ističu kako je dobro koje se pruža informacija, a ciljna skupina lobističke aktivnosti zakonodavac ili donositelj (političkih) odluka. Navode kako lobiranje uključuje niz taktika kao što su izravno lobiranje, izvještavanje o rezultatima istraživanja, lansiranje specifičnih istraživanja, svjedočenja stručnjaka i predstavljanje tehničkih izvještaja donositeljima odluka. Dodatno, kako bi se postigli željeni ishodi javnih politika, važnim smatraju razvijanje snažnog ugleda, kako bi donositelji odluka bili skloni 
DRUŠ. ISTRAŽ. ZAGREB GOD. 21 (2012) BR. 2 (116),

STR. 545-567

SINČIĆ ĆORIĆ, D., VUKOVIĆ, I.: ANALIZA TISKOVNIH. vjerovati pruženim informacijama te kako bi se ubuduće ponovno obratili lobistima kad raspravljaju o određenoj javnoj politici.

McGrath (2006.) ističe važnost personaliziranih i izravnih kontakata s donositeljima odluka za rad i djelovanje lobista te navodi kako bi se upravo zbog toga lobiranje moglo definirati unutar marketinga odnosa. Marketing odnosa u centar zbivanja stavlja osobni odnos između sudionika u razmjeni, a kako su osobni kontakti vrlo važni za uspjeh u lobiranju, može se reći kako je strateška upotreba lobiranja marketinški usredotočena aktivnost.

Keffer i Hill (1997.) argumentiraju kako se lobiranje treba rabiti kao važan element prilikom razvoja marketinških planova organizacija, pa stoga definiraju lobiranje kao važan strateški marketinški alat organizacije.

Harris i Lock (1996.) napominju kako je teško odrediti koliko se aktivnosti lobiranja trenutačno provodi s obzirom na poteškoće u definiranju preciznih različitosti i granica između lobiranja i ostalih oblika komunikacijskih aktivnosti, kao i zbog vrlo čestih ugovora o tajnosti između poslovnih klijenata i lobista. Oni predlažu definiciju lobiranja vezanu uz marketinške aktivnosti poduzeća, ističući da je lobiranje mobiliziranje javnih mišljenja kako bi se stvorio pritisak na donositelje javnih odluka u svrhu stvaranja poslovnoga dobitka ili poboljšanja konkurentske pozicije poduzeća. U prilog toj definiciji govore i De Figueiredo i Tiller (2001.), koji smatraju da poduzeće, kako bi stvorilo vrijednost i ostvarilo dobit, poduzima određene tržišne i netržišne aktivnosti. U netržišne aktivnosti autori ubrajaju i lobiranje, odnosno aktivnosti koje poduzeće poduzima u svojem političkom, zakonodavnom i društvenom okruženju. S tim u vezi poduzeća često rabe lobiranje kao marketinšku aktivnost kako bi povećala prodaju, diferencijaciju organizacije ili poboljšanje lojalnosti kupaca. Takvo lobiranje naziva se i "glasnim" lobiranjem (Harrison, 2000.).

Zaključno, lobiranje se u kontekstu hrvatskog okruženja i prisutnog opsega lobističkih aktivnosti može shvatiti kao prijenos relevantnih informacija od različitih interesnih skupina (poduzeća, neprofitnih organizacija i slično) dionicima različitih razina i oblika vlasti, kako bi se utjecalo na donošenje (javnih) odluka.

\section{RAZVIJENOST LOBIRANJA U HRVATSKOJ}

Cox i Mason (2000.) navode kako je u komunističkim režimima politički poredak snažno ograničavao prostor za razvoj interesnih organizacija i autonomno zastupanje njihovih interesa pred tijelima javne vlasti. Na početku devedesetih godina 20. stojeća Republika Hrvatska, kao i ostatak Jugoistočne Europe i bivših zemalja SSSR-a, procesom političke, društvene i eko- 
DRUŠ. ISTRAŽ. ZAGREB GOD. 21 (2012), BR. 2 (116)

STR. 545-567

SINČIĆ ĆORIĆ, D., VUKOVIĆ, I.: ANALIZA TISKOVNIH... nomske tranzicije i, konačno, Ustavom Republike Hrvatske građanima omogućuje pravo na slobodno udruživanje u sindikate i udruge s ciljem zaštite svojih interesa te slobodu govora i izražavanja mišljenja. Navedene su okolnosti, navodi McGrath (2008.), dovele do eksponencijalnog rasta broja, oblika i mogućnosti interesnoga zastupanja i lobiranja pred tijelima javne vlasti, što postaje izraženije njihovim približavanjem članstvu u EU. Perez-Solorzano Borragan (2005., prema Vidačak, 2007.) zaključuje kako unatoč velikom broju interesnih skupina, njihovo djelovanje karakterizira manjak jasnih strategija, vještina i organiziranosti, nerazumijevanje pravila i standarda zastupanja interesa razvijenih u zapadnim demokracijama i neshvaćanje koncepta lobiranja i mogućnosti koje ono pruža. Čak i poslovni akteri, koji se smatraju avangardom sektorskoga zastupanja interesa, nerijetko se suočavaju s poteškoćama u razvoju temeljnih lobističkih vještina (IMO, 2004.). Sve važniju ulogu u oblikovanju javnih politika i procesima odlučivanja dobivaju specifični oblici lobističkih organizacija, tzv. Think-Tank. McGann (2010.) prepoznaje deset takvih u Hrvatskoj.

Vlahović (2009.) ističe da u Hrvatskoj nema registracije lobista ili interesnih organizacija u bilo kojoj od političkih institucija. Razvoj profesionalne lobističke industrije još je na početku i ne može se utvrditi koliki je približni prihod od lobiranja u Hrvatskoj. S druge strane, Hrvatska je svojevrstan vođa u organiziranju lobista i želji za regulacijom lobiranja. ${ }^{2}$ Vidačak (2007.) smatra da je jedan od najvažnijih koraka u profesionalizaciji i regulaciji lobiranja u Hrvatskoj učinjen osnivanjem Hrvatskog društva lobista u lipnju 2008. godine, kao prvoga profesionalnog lobističkog udruženja u Jugoistočnoj Europi koje se zalaže za profesionalizaciju i regulaciju lobiranja.

OECD (2009.) navodi da inicijativa za regulaciju lobiranja u Hrvatskoj dolazi od samih lobista, da članovi Društva potpisuju Etički kodeks koji je usklađen s europskim kodeksom te da je na inicijativu HDL-a Ministarstvo pravosuđa pokrenulo radnu skupinu koja će utvrditi potrebu za zakonskom regulacijom lobiranja. Vlada Republike Hrvatske uvrstila je usvajanje zakona o lobiranju u četvrti kvartal 2010. Akcijskog plana uz strategiju suzbijanja korupcije, no unatoč tome zakon nije stupio na snagu.

Ulaskom u završnu fazu pregovora o pristupanju Europskoj uniji jača interes i potreba organizacija iz Hrvatske za lobiranje u Bruxellesu. Perez-Solorzano Borragan (2002.) upućuje na nekoliko mogućih kanala utjecaja interesnih skupina iz Jugoistočne Europe u procesima donošenja odluka na razini Unije u pretpristupnom razdoblju: nacionalna vladina tijela i diplomatska predstavništva, vlastiti interesni predstavnički uredi te srodna sektorska interesna udruženja. Od nacionalnih vla- 
DRUŠ. ISTRAŽ. ZAGREB GOD. 21 (2012) BR. 2 (116)

STR. 545-567

SINČIĆ ĆORIĆ, D., VUKOVIĆ, I.: ANALIZA TISKOVNIH... dinih tijela i diplomatskih predstavništava u Bruxellesu djeluje Misija RH pri Europskim zajednicama, Misija RH pri NATO-u, Veleposlanstvo RH pri Kraljevini Belgiji i ured Hrvatske turističke zajednice.

Vidačak (2006.) zaključuje da se napretkom procesa pristupanja Hrvatske Uniji postupno počinju razvijati sofisticiraniji oblici pluralističkoga zastupanja interesa, pa interesne skupine sve više zahtijevaju aktivniju ulogu u interakciji s institucijama EU-a, užu suradnju s partnerskim organizacijama na razini EU-a, a manji dio se odlučuje i na otvaranje vlastitih predstavničkih ureda u Bruxellesu. Uza sve češće otvaranje interesnih predstavničkih ureda u sjedištu Unije, počinje se, uz već postojeće diplomatske kanale, razvijati nova tvz. paralelna diplomacija, odnosno novi oblici izravnoga zastupanja interesa različitih sektora i društvenih aktera.

Od gospodarskih predstavnika svoje urede u Bruxellesu otvorili su Hrvatska gospodarska komora (HGK) 2000. godine i Hrvatska obrtnička komora (HOK) 2005. godine. Od ostalih gospodarskih udruga svoja predstavništva otvorili su Zaklada za promicanje gospodarskih interesa i Hrvatska EU poslovno vijeće (Croatia EU Business Council - CEUBC). Otvaranje ureda regionalnih predstavništava u Bruxellesu započinje 2005. godine, kada se otvara Ured Istarske županije, a 2007. Ured Regionalne razvojne agencije Slavonije i Baranje. Iste godine na inicijativu Agencije za razvoj Varaždinske županije otvoren je Ured hrvatskih regija koji zastupa interese pet županija, osam gradova i dvije razvojne agencije. Godine 2010. Dubrovačko-neretvanska županija otvara predstavnički ured.

Kako bi se potaknula povezanost i horizontalna suradnja između predstavništava interesnih skupina iz Hrvatske $u$ Bruxellesu, u lipnju 2007. godine osnovana je Hrvatska poslovna mreža (Croatian Business Network - CBN). Ciljevi CBN-a jesu objedinjavanje aktivnosti svih hrvatskih predstavništava u Bruxellesu kako bi se postigla bolja vidljivost hrvatskih poslovnih interesa u briselskim krugovima, bolja informiranost, razmjena iskustava, bolja koordinacija aktivnosti, a time i veći poslovni uspjesi. Koordinator CBN-a jest Ured HGK u Bruxellesu, a jednom u tjednu održavaju međusobne sastanke (Veleposlanstvo RH u Kraljevini Belgiji, 2007.).

Još jedan od pokazatelja zastupljenosti hrvatskih interesa u središtu EU-a jest i broj registriranih lobista pri institucijama Unije. U Registru lobista Europskog parlamenta u prosincu 2010. godine od ukupno 5092 registriranih lobista bilo je šest iz Hrvatske (European Parliament, 2010.), a u Registru interesnih organizacija Europske komisije u kojem je registrirano 3308 organizacija bilo je pet organizacija koje su zastupale hrvatske interese pri toj instituciji (European Commission, 2010.). Zanimljivo je da su pri Komisiji i Parlamentu registrirani lobisti i organizacije iz Hrvatske. 


\section{ANALIZA NOVINSKIH I INTERNETSKIH OBJAVA O LOBIRANJU U REPUBLICI HRVATSKOJ}

\section{Problem, cilj i polazne pretpostavke istraživanja}

Prethodno opisano stanje lobiranja u Hrvatskoj upućuje na činjenicu da je lobistička struka u Hrvatskoj u vrlo ranoj fazi razvoja, u kojoj je uloga medija u pozicioniranju među općom javnosti vrlo važna. Imajući navedeno na umu, cilj rada jest istražiti i analizirati novinske i internetske objave o lobiranju u Hrvatskoj, kako bi se na temelju nalaza upozorilo na prevladavajuću intonaciju i važnost pojma u sadržajima koji se vežu uz pojam lobiranja. Pri tome se polazi od sljedećih polaznih pretpostavki:

P1: Sadržaji o lobiranju u kojima je lobiranje glavni (dominantni) pojam dominantno su pozitivno intonirani.

P2: Sadržaji o lobiranju u kojima je lobiranje sporedan pojam dominantno su neutralno intonirani.

P3: Sadržaji o lobiranju u kojima se lobiranje kao pojam samo spominje dominantno su negativno intonirani.

P4: Sadržaji o lobiranju u kojima se lobiranje analizira u poslovnom kontekstu dominantno su pozitivno intonirani.

P5: Sadržaji o lobiranju u kojima se lobiranje analizira u političkom kontekstu dominantno su negativno intonirani.

P6: Sadržaji o lobiranju u kojima se lobiranje kao pojam povezuje s pojmom "Europska unija" dominantno su pozitivno intonirani.

Navedene pretpostavke temelje se na empiriji, odnosno na preliminarnom istraživanju tekstova o lobiranju. Potporu ovakvu stajalištu iznosi Krippendorff, koji kaže da su "dva razloga zašto je analizu sadržaja bolje započeti istraživačkim pitanjem, a ne hipotezom: učinkovitost i empirijska utemeljenost" (2004., str. 33). Dodatno, Kolbe i Burnett (1991.) navode da u $48 \%$ studija istraživači temelje analizu sadržaja na istraživačkim pitanjima ili pretpostavkama (eksploraciji, a ne konfirmaciji), odnosno na očekivanjima od analize, a ne na teoriji i formalnim hipotezama.

\section{Metoda istraživanja}

Kako bi se ostvario postavljeni cilj istraživanja, provedena je kvantitativna (frekvencijska) analiza sadržaja tekstova koji su objavljeni u tisku i na internetskim portalima. Analizom su se provjerili (1) prisutnost pojma lobiranje, (2) frekvencija pojavljivanja pojma lobiranje, (3) odnos povoljnih i nepovoljnih o- 
DRUŠ. ISTRAŽ. ZAGREB GOD. 21 (2012) BR. 2 (116),

STR. 545-567

SINČIĆ ĆORIĆ, D. VUKOVIĆ, I.: ANALIZA TISKOVNIH. bilježja vezanih uz pojam lobiranje, (4) tipovi kvalifikacije (intonacije) pojma lobiranje i (5) frekvencija zajedničkoga pojavljivanja pojmova lobiranje i Europska unija. Navedenih pet indicija (prisutnost / odsutnost pojma ili koncepta; frekvencija pojavljivanja simbola, ideje ili pojma; odnos povoljnih i nepovoljnih obilježja vezanih uz pojam ili koncept; kvalifikacije korištene u opisima pojma, simbola ili ideje i frekvencija zajedničkog pojavljivanja dva koncepta) slažu se s onima koje Krippendorff (2004., str. 59) opisuje kao dugotrajno prisutne indicije analize sadržaja $\mathrm{u}$ istraživanju masovne komunikacije.

\section{Izvori, uzorak i jedinice analize sadržaja}

Za analizu sadržaja treba izabrati izvore koji su pristupačni istraživaču i koji sadrže neposredne, iscrpne i pouzdane podatke (Žugaj, 1997.). Stoga su kao izvori analize odabrane dnevne, tjedne i mjesečne novine te internetski portali.

Ukupno je analizirano 512 objava, od čega je 412 članaka objavljeno u pedeset trojim novinama, a 100 članaka objavljeno je na ukupno 21 internetskom portalu. Analizirane su objave od 1. 1. 2009. do 1. 7. 2010. godine. Frekvencije njihovih objava prikazane se u Tablici 1. ${ }^{3}$ Analizirani su cjeloviti članci koji su u naslovu ili tekstu sadržavali riječi "lobiranje", "lobisti", "lobistički" i/ili "lobist".

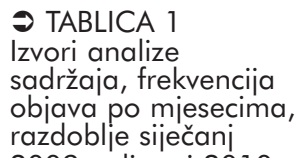

\begin{tabular}{crrr}
\hline Mjesec/godina & Tisak & Internet & Ukupno \\
\hline $1 / 09$. & 7 & 5 & 7 \\
$2 / 09$. & 10 & 1 & 11 \\
$3 / 09$. & 20 & 0 & 20 \\
$4 / 09$. & 18 & 0 & 18 \\
$5 / 09$. & 11 & 0 & 11 \\
$6 / 09$. & 16 & 2 & 18 \\
$7 / 09$. & 15 & 0 & 15 \\
$8 / 09$. & 15 & 1 & 16 \\
$9 / 09$. & 27 & 4 & 31 \\
$10 / 09$. & 29 & 3 & 32 \\
$11 / 09$. & 35 & 2 & 37 \\
$12 / 09$. & 29 & 3 & 32 \\
$1 / 10$. & 28 & 8 & 36 \\
$2 / 10$. & 13 & 2 & 15 \\
$3 / 10$. & 34 & 1 & 35 \\
$4 / 10$. & 37 & 8 & 45 \\
$5 / 10$. & 36 & 23 & 59 \\
$6 / 10$. & 32 & 37 & 69 \\
Ukupno & 412 & 100 & 512 \\
\hline
\end{tabular}

Broj sadržaja o pojmu "lobiranje" s vremenom raste. U prvoj polovici 2009. godine objavljena su 82 sadržaja u novi- 
(1) TABLICA 2

Izvori analize

sadržaja, distribucija

prema površini članka,

razdoblje siječanj

2009. - lipani 2010.

(polugodišnji zbrojevi) godine taj se broj popeo na 150 objava članaka u novinama i 13 na internetskim portalima, dok je samo u prvoj polovici 2010. godine taj broj dosegnuo 180 objava članaka u novinama i 79 na internetskim portalima. Prema veličini članaka, mjerenoj u milimetrima prostora, najzastupljeniji su članci od 301 do 600 $\mathrm{mm}$. Njihov je udio u ukupnom broju objava u novinama $25 \%$ (103 članka), dok je udio u ukupnom broju objava na internetskim portalima 44\% (44 članka) (Tablica 2).

\begin{tabular}{|c|c|c|c|c|c|c|c|c|}
\hline \multirow[b]{2}{*}{ Površina (mm) } & \multirow[b]{2}{*}{ tisak } & \multirow[b]{2}{*}{ 1.-6. 09 . } & \multirow[b]{2}{*}{ 7.-12. 09.} & \multirow[b]{2}{*}{ 1.-6. 10 . } & \multirow[b]{2}{*}{ web } & \multicolumn{3}{|c|}{ Broj članaka } \\
\hline & & & & & & 1.-6. 09 . & 7.-12. 09 . & 1.-6. 10 . \\
\hline $0-50$ & 35 & 10 & 19 & 6 & 0 & 0 & 0 & 0 \\
\hline $51-150$ & 67 & 11 & 24 & 32 & 12 & 3 & 0 & 8 \\
\hline $151-300$ & 64 & 15 & 21 & 28 & 34 & 4 & 4 & 26 \\
\hline $301-600$ & 103 & 25 & 39 & 39 & 44 & 1 & 7 & 36 \\
\hline 601-1000 & 59 & 8 & 19 & 32 & 9 & 0 & 1 & 8 \\
\hline $1001-2000$ & 65 & 10 & 22 & 33 & 1 & 0 & 1 & 0 \\
\hline $2001-$ & 19 & 3 & 6 & 10 & 1 & 0 & 0 & 1 \\
\hline Ukupno & 412 & 82 & 150 & 180 & 100 & 8 & 13 & 79 \\
\hline
\end{tabular}

(1) SLIKA 1

Distribucija članaka u novinama po miesecima, razdoblie siječani 2009. lipanj 2010.
Crta trenda $(y=1,4923 x+8,7124)$, koji se temelji na podacima distribucije objava članaka u novinama po mjesecima (Slika 1), ima uzlazan rast i pokazuje da se broj objava kroz vrijeme povećava. Koeficijent determinacije opisuje $63 \%$ podataka.

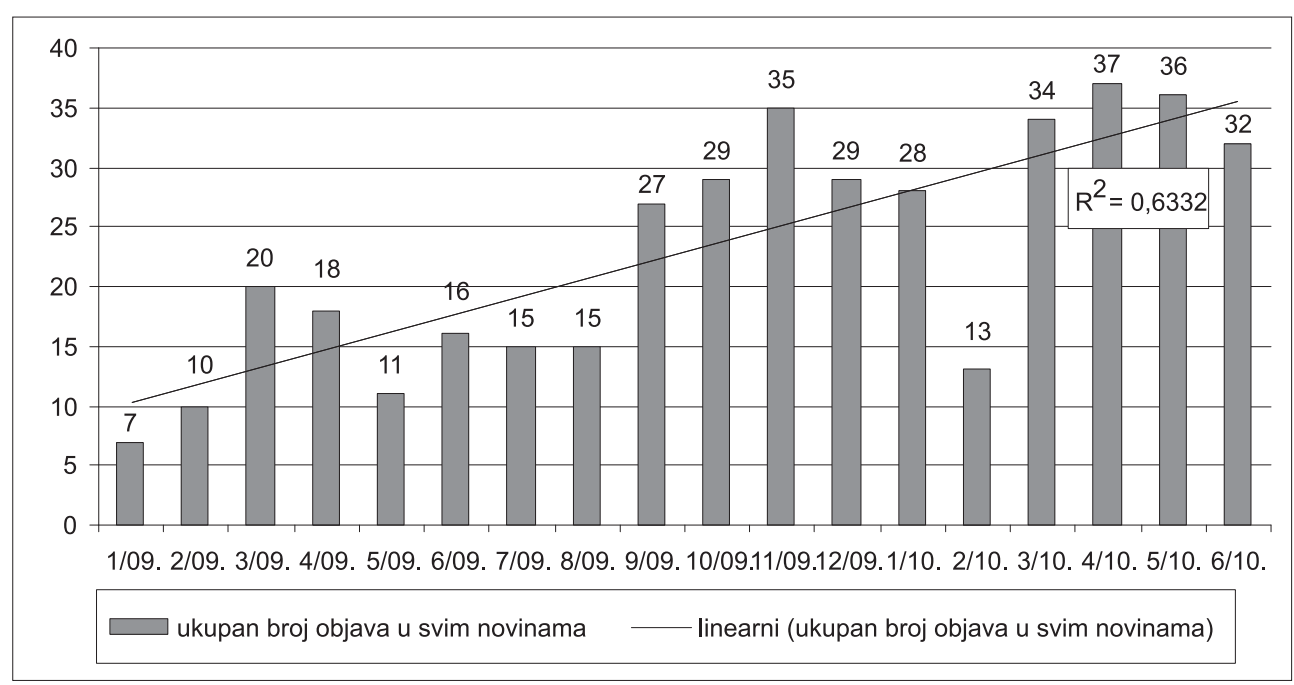

Iz Slike 2 (temeljene na Tablici u Prilogu 1) može se vidjeti da je broj objava koncentriran u pojedinim novinama, pri čemu je najveća koncentracija u dnevnim novinama (255 ili $61,89 \%$ od ukupnoga broja objava u promatranom razdoblju), a najmanja u dvotjednim novinama (samo 1 ili 0,24\%). 


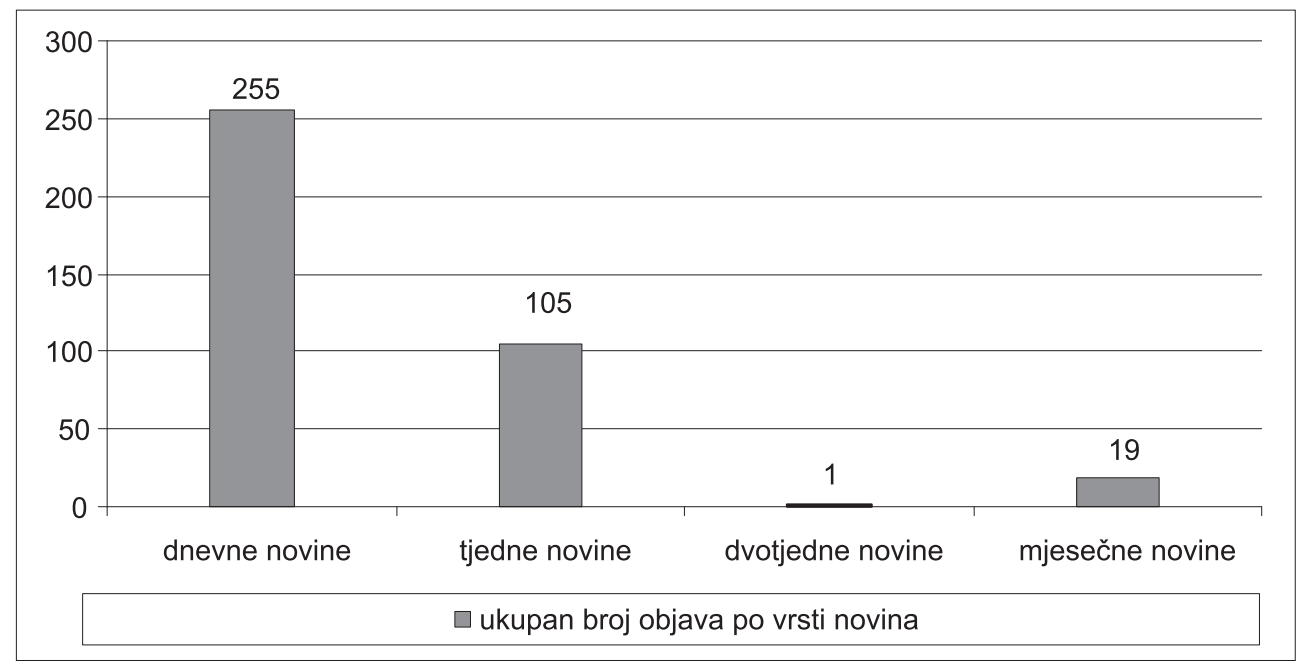

i SLIKA 2

Koncentracija članaka po vrsti novina, ukupne objave od siječnja 2009. do lipnja 2010 .

(1) SLIKA 3

Distribuciia članaka na internetskim portalima po mjesecima, razdoblje siječanj 2009. lipani 2010.
Crta trenda $(y=1,1001 x-4,8954)$, temeljena na podacima distribucije objava članaka na internetskim portalima po mjesecima (Slika 3, temeljena na Tablici u Prilogu 2), također ima uzlazan rast i pokazuje da se broj objava kroz vrijeme povećava, no ovaj zaključak manje je precizan jer je koeficijentom determinacije opisano 38\% podataka. Iz Tablice u Prilogu 2 vidi se da su objave relativno jednako raspršene na svim internetskim portalima, s blagom koncentracijom broja objava na četiri od ukupno dvadeset i jednog analiziranog portala.

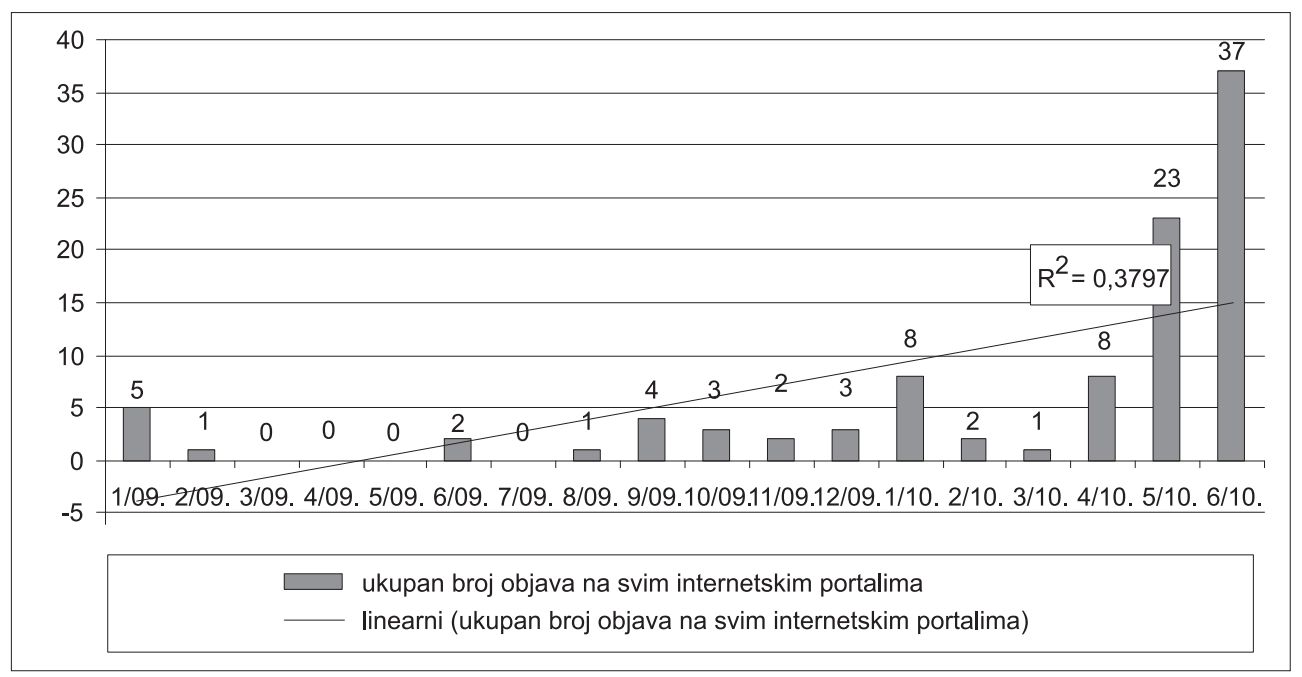

\section{Kategorije analize sadržaja}

Analiza sadržaja provedena je na temelju kategorija, odnosno obilježja, sadržajne prirode. Tekstovi su analizirani s obzirom na:

1. Intonaciju članka. U svakom je članku analiziran prevladavajući ton članka. S obzirom na to svaki je članak kodi- 
DRUŠ. ISTRAŽ. ZAGREB GOD. 21 (2012), BR. 2 (116)

STR. 545-567

SINČIĆ ĆORIĆ, D., VUKOVIĆ, I.: ANALIZA TISKOVNIH... ran odgovarajućom oznakom: oznakom "+" za prevladavajuće pozitivan ton, oznakom "0" za prevladavajuće neutralan ton i oznakom "-" za prevladavajuće negativan ton.

2. Važnost i položaj pojma "lobiranje" i inačica koje se analiziraju u članku. Svaki je članak analiziran s obzirom na to kako je uobličen sadržaj, odnosno je li lobiranje glavni (dominantan) pojam, sporedni pojam ili se u članku samo spominje (u kontekstu koji nije nužno vezan uz bilo kakvu informaciju o lobiranju). Članci u kojima je lobiranje glavni (dominantan) pojam označeni su oznakom "A", oni u kojima je lobiranje sporedni pojam označeni su oznakom "B", dok su oni u kojima se lobiranje samo spominje označeni oznakom " $\mathrm{C}$ ".

3. Smještaj pojma "lobiranje" u širem nacionalnom društvenom kontekstu. Svaki je članak označen s obzirom na to je li lobiranje analizirano iz političke (oznakom "P") ili poslovne (oznakom "B") perspektive.

4. Smještaj pojma "lobiranje" $u$ širem međunarodnom društvenom kontekstu, odnosno je li lobiranje analizirano u kontekstu pristupanja Europskoj uniji ili je na bilo koji način povezano s pojmom ili aktivnostima vezanima uz Europsku uniju.

\section{Kriteriji kvalitete analize}

Tkalac Verčič i sur. (2010.) navode kako je odlika dobre analize sadržaja objektivnost, koja se postiže dobrom pripremom i vježbom analitičara, ograničavanjem broja kategorija koje se analiziraju i triangulacijom istraživača. Više je načina kojima se nastojala postići visoka razina kvalitete analize. (1) Kako bi se osigurala objektivnost analize, istraživači su samostalno analizirali svaki informacijski materijal, odnosno provedena je triangulacija istraživača $u$ fazi analize. ${ }^{4}$ Istraživači su potom usporedili nalaze i postigli konsenzus oko zaključaka. Koeficijent slaganja iznosio je 0,9 , što predstavlja visoku razinu pouzdanosti. ${ }^{5}$ Neslaganja istraživača potom su razriješena raspravom te je postignut konsenzus oko svih nalaza. (2) Prvi nalazi analize dani su na procjenu dvama nezavisnim sucima, ${ }^{6}$ kako bi se provjerila objektivnost nalaza istraživača (Kolbe i Burnett, 1991.). (3) Analiza sadržaja provedena je prema unaprijed utvrđenim kriterijima. (4) Broj kategorija koje su analizirane bio je prihvatljiv u smislu njihova broja (količine). (5) Istraživači su prethodno provodili analizu sadržaja. Navedena obilježja Silverman (1997.) opisuje kao uvjete kojima se osigurava valjanost i pouzdanost analize.

\section{REZULTATI}

Rezultati analize strukturirani su tako da se najprije prikazuje zastupljenost pojma lobiranje prema prevladavajućem tonu sadržaja i oblikovanju sadržaja u materijalu, zatim se prikazuje zastupljenost pojma lobiranje prema prevladavajućem tonu i 
smještaju sadržaja u društvenom kontekstu, nakon čega se opisuju ograničenja analize.

\section{Zastupljenost pojma lobiranje prema prevladavajućem tonu sadržaja i oblikovanju sadržaja u materijalu}

Postoci zastupljenosti pojma lobiranje $u$ analiziranom materijalu izračunani su po formuli $p=n \bullet 100 / N$ (Vujević, 2000.), gdje je $p$ postotak zastupljenosti, $n$ broj jedinica određene kategorije, a $N$ ukupan broj jedinica za sve kategorije.

Ovako izračunan, postotak pozitivno intoniranih tekstova o lobiranju iznosi $28,9 \%$, postotak neutralno intoniranih tekstova o lobiranju iznosi $28,2 \%$, dok je postotak negativno intoniranih tekstova o lobiranju $27,3 \%$.

$\mathrm{Na}$ temelju postotaka izračunan je koeficijent neravnoteže, po formuli $K n=F a-N e / n$ (Vujević, 2000.), gdje je Kn koeficijent neravnoteže, $\mathrm{Fa}$ su pozitivno intonirane jedinice, $\mathrm{Ne}$ negativno intonirane jedinice, a $n$ ukupan broj jedinica (pozitivno, negativno i neutralno intoniranih) sadržaja. Koeficijent neravnoteže iznosi 0,02 . On upućuje na to da je sadržaj o lobiranju ravnomjerno intoniran, odnosno da su odnosi pozitivno, neutralno i negativno intoniranih tekstova ravnotežni.

Kada se $u$ analizu uključe i kategorije oblikovanja sadržaja, odnosno informacija o tome je li lobiranje glavni (dominantan) pojam, sporedan pojam ili se u članku samo spominje (u kontekstu koji nije nužno vezan uz bilo kakvu informaciju o lobiranju), vide se sljedeći nalazi:

1. Sadržaji u kojima je lobiranje glavni pojam dominantno su pozitivno intonirani $(63,5 \%$ od ukupnoga broja članaka u kojima je lobiranje glavni pojam, odnosno 9,2\% od ukupnoga broja članaka). Rezultati su u skladu s polaznom pretpostavkom P1: sadržaji o lobiranju u kojima je lobiranje glavni (dominantni) pojam dominantno su pozitivno intonirani.

2. Sadržaji u kojima je lobiranje sporedni pojam dominantno su negativno intonirani (52,3\% od ukupnoga broja članaka u kojima je lobiranje sporedan pojam, odnosno $11,3 \%$ od ukupnoga broja članaka), što je u suprotnosti s polaznom pretpostavkom P2: sadržaji o lobiranju u kojima je lobiranje sporedni pojam dominantno su neutralno intonirani.

3. Sadržaji u kojima se lobiranje samo spominje dominantno su negativno intonirani (41,3\% od ukupnoga broja članaka u kojima je lobiranje sporedan pojam, odnosno $29,9 \%$ od ukupnoga broja članaka), što odgovara polaznoj pretpostavci P3: sadržaji o lobiranju u kojima se lobiranje kao pojam samo spominje dominantno su negativno intonirani.

Koeficijent neravnoteže iznosi - 0,32 i upućuje na to da je sadržaj o lobiranju neravnomjerno intoniran, s obzirom na obilježje važnosti i položaja pojma u članku, to jest da su prisutniji negativno intonirani sadržaji. 


\section{Zastupljenost pojma lobiranje prema prevladavajućem tonu i smještaju sadržaja u društvenom kontekstu}

Postotak sadržaja u kojima se lobiranje analizira iz političke perspektive iznosi $71,9 \%$, dok je postotak sadržaja u kojima se lobiranje analizira iz poslovne perspektive $28,1 \%$. Koeficijent neravnoteže iznosi 0,43 i upućuje na to da je sadržaj o lobiranju iz političke perspektive $\mathrm{u}$ odnosu na sadržaj o lobiranju iz poslovne perspektive $u$ značajnoj mjeri prisutniji.

Kada se $\mathrm{u}$ analizu uključe prethodne kategorije - prevladavajuće intonacije i oblikovanja sadržaja, odnosno je li sadržaj pozitivno, neutralno ili negativno intoniran te je li lobiranje glavni (dominantan) pojam, sporedan pojam ili se u članku samo spominje, vidi se da:

1. Sadržaji u kojima je lobiranje glavni pojam dominantno su pozitivno intonirani, bez obzira na to je li lobiranje analizirano iz političke ili poslovne perspektive.

2. Sadržaji u kojima je lobiranje sporedan pojam dominantno su negativno intonirani, bez obzira na to je li lobiranje analizirano iz političke ili poslovne perspektive.

Frekvencija članaka s obzirom na obiliežja intonacije članka, važnosti i položaja poima te smieštaja u nacionalni društveni kontekst, razdoblje siječani 2009. lipani 2010.

3. Sadržaji u kojima se lobiranje kao pojam samo spominje dominantno su negativno intonirani u slučajevima u kojima je lobiranje analizirano iz političke perspektive, dok su dominanto neutralno intonirani u slučajevima u kojima je lobiranje analizirano iz poslovne perspektive. Njihova je ukupna intonacija također negativna (Tablica 3).

\begin{tabular}{lcccc}
\hline & $\begin{array}{c}\text { Pozitivno } \\
\text { intonirani }\end{array}$ & $\begin{array}{c}\text { Neutralno } \\
\text { intonirani }\end{array}$ & $\begin{array}{c}\text { Negativno } \\
\text { intonirani }\end{array}$ & Ukupno \\
\hline Članci u kojima je lobiranje glavni pojam (A) & 31 & 13 & 3 & 47 \\
Poslovna perspektiva lobiranja & 16 & 3 & 8 & 27 \\
Politička perspektiva lobiranja & 47 & 16 & 11 & 74 \\
Ukupno & & & & \\
Članci u kojima je lobiranje sporedan pojam (B) & 9 & 4 & 17 & 30 \\
Poslovna perspektiva lobiranja & 25 & 15 & 41 & 81 \\
Politička perspektiva lobiranja & 34 & 19 & 58 & 111 \\
Ukupno & & & & \\
Članci u kojima je lobiranje pojam koji se spominje (C) & 18 & 28 & 21 & 67 \\
Poslovna perspektiva lobiranja & 49 & 79 & 132 & 260 \\
Politička perspektiva lobiranja & 67 & 107 & 153 & 327 \\
Ukupno & & & & \\
\hline
\end{tabular}

Kao i u prethodnom slučaju, koeficijent neravnoteže iznosi - 0,32 i upućuje na to da je sadržaj o lobiranju neravnomjerno intoniran, s obzirom na obilježja važnosti i položaja pojma u članku te smještaja pojma u nacionalni društveni kontekst, to jest da su prisutniji negativno intonirani sadržaji. Važno je ta- 
DRUŠ. ISTRAŽ. ZAGREB GOD. 21 (2012) BR. 2 (116)

STR. 545-567

SINČIĆ ĆORIĆ, D. VUKOVIĆ, I.: ANALIZA TISKOVNIH..

(1) TABLICA 4

Frekvencija članaka kojima se lobiranje analizira u kontekstu pristupanja Europskoj uniji s obzirom na obiliežja intonacije članka, razdoblje siiečani 2009. lipanj 2010 kođer istaknuti da je očita dominacija pozitivne intonacije članaka u kojima je lobiranje glavni pojam. Naknadnom analizom utvrđeno je da su to članci koji se detaljno bave opisom djelatnosti, uključenih osoba, pozitivnih ishoda procesa lobiranja i slično, dok se u člancima u kojima se lobiranje samo spominje ono najčešće stavlja u kontekst posredništva ili kriminala ili se u njima opisuju neuspjeli pokušaji lobiranja pri lokalnim ili državnim tijelima odlučivanja.

Sve navedeno upućuje na zaključak da se polazna pretpostavka P4: sadržaji o lobiranju u kojima se lobiranje analizira u poslovnom kontekstu dominantno su pozitivno intonirani ne može smatrati točnom, jer su prisutniji negativno intonirani sadržaji, što je u skladu s polaznom pretpostavkom P5: sadržaji o lobiranju u kojima se lobiranje analizira u političkom kontekstu dominantno su negativno intonirani.

Broj sadržaja u kojima se lobiranje analizira u kontekstu pristupanja Europskoj uniji ili je na bilo koji način povezano s pojmom ili aktivnostima vezanima uz Europsku uniju iznosi 32, pri čemu je trećina sadržaja posvećena političkoj perspektivi lobiranja u Europskoj uniji (22 članka), a ostatak razmatra poslovnu perspektivu lobiranja u Europskoj uniji (10 članaka). Članci su dominantno pozitivno (14 članaka) i neutralno (14 članaka) intonirani (Tablica 4). Udio ovih sadržaja u ukupnom broju tekstova relativno je malen i iznosi $6,25 \%$.

\begin{tabular}{lcccc}
\hline & $\begin{array}{c}\text { Pozitivno } \\
\text { intonirani }\end{array}$ & $\begin{array}{c}\text { Neutralno } \\
\text { intonirani }\end{array}$ & $\begin{array}{c}\text { Negativno } \\
\text { intonirani }\end{array}$ & Ukupno \\
\hline Poslovna perspektiva lobiranja & 5 & 4 & 1 & 10 \\
Politička perspektiva lobiranja & 9 & 10 & 3 & 22 \\
Ukupno & 14 & 14 & 4 & 32 \\
\hline
\end{tabular}

Polazna pretpostavka P6: sadržaji o lobiranju u kojima se lobiranje kao pojam povezuje s pojmom "Europska unija" dominantno su pozitivno intonirani ne može se potvrditi, jer su sadržaji ravnomjerno pozitivno i neutralno intonirani.

\section{Ograničenja analize}

Istraživanje obilježavaju dva nedostatka. (1) Analizirani informacijski materijal uključuje tiskovni materijal i objave na internetskim portalima. Objave na radijskim i televizijskim postajama nisu uključene $u$ analizu. Stoga se nalazi ne mogu poopćavati na cijeli informacijski (medijski) prostor, nego samo na analizirane kanale komuniciranja. (2) Postoji mogućnost pristranosti istraživača (analitičara) $\mathrm{u}$ analizi odnosno procjeni sadržaja. Taj se nedostatak nastojao prevladati zasebnim postupcima analize te konsenzusom oko nalaza. 
Provedena analiza upućuje na dva opća zaključka. Prvo, s obzirom na relativno kratku povijest lobiranja kao djelatnosti u Hrvatskoj, broj sadržaja koji se bave lobiranjem vrlo je velik i u porastu. Količini sadržaja pogodovao je interes medija za informacije o djelatnosti (što je osobito vidljivo u sadržajima koji su posvećeni opisu djelatnosti, aktivnostima i/ili ishodima lobističkih aktivnosti), ali i primjena pojma u svrhe koje nemaju veze sa samim pojmom (što se vidi iz sadržaja u kojima se pojam "lobiranje" rabi kao sporedan pojam, u svrhu opisa neučinkovitoga nastojanja pri donošenju odluka, korumpiranoga ponašanja ili kriminalne radnje). Unatoč relativno velikoj zastupljenosti pojma "lobiranje" u tiskovnim i internetskim sadržajima, velike različitosti u njegovu shvaćanju, kao i upotreba pojma u negativnom kontekstu, ne pogoduju jedinstvenom definiranju lobiranja ni njegovu jasnom pozicioniranju u javnostima, što je izazov teoretičarima i praktičarima lobiranja.

Drugo, sadržaji o lobiranju vrlo su različito intonirani s obzirom na kategorije analize. Sadržaji u kojima je lobiranje glavni pojam, odnosno oni u kojima se detaljnije opisuje djelatnost, stručnjaci koji se bave lobiranjem, ili pozitivni ishodi provedenih postupaka lobiranja, dominantno su pozitivno intonirani, bez obzira na to je li lobiranje analizirano iz političke ili poslovne perspektive. Provedena analiza potvrdila je, dakle, polaznu pretpostavku P1: sadržaji o lobiranju u kojima je lobiranje glavni (dominantni) pojam dominantno su pozitivno intonirani. S druge strane, sadržaji u kojima je lobiranje sporedan pojam ili se ono samo spominje, najčešće u kontekstu posredništva, kriminala ili neuspjelih postupaka utjecanja na lokalna ili državna tijela odlučivanja, dominantno su negativno intonirani, bez obzira na to je li lobiranje analizirano iz političke ili poslovne perspektive (uz iznimku sporednoga spominjanja lobiranja u poslovnom kontekstu, kada je ono predočeno neutralnim tonom). Navedeni rezultati opovrgavaju polaznu pretpostavku P2: sadržaji o lobiranju u kojima je lobiranje sporedni pojam dominantno su neutralno intonirani, a potvrđuju polaznu pretpostavku P3: sadržaji o lobiranju u kojima se lobiranje kao pojam samo spominje dominantno su negationo intonirani. Količina pozitivno intoniranih tekstova u kojima je lobiranje glavni pojam pokazuje da pozitivni ishodi lobističkih aktivnosti kao i pozitivna nastojanja struke (lobista i udruženja) u razvoju i promoviranju struke imaju određeni utjecaj na oblikovanje medijskoga sadržaja o lobiranju. Navedeno pruža priliku da se sličnim naporima kroz dulje vrijeme struka predstavi kao pozitivna, etična i transparentna. Vjerojatno će i nastojanja lobista da se donese Zakon o lobiranju pridonijeti njezinoj povoljnijoj percepciji.

Rezultati analize nadalje opovrgavaju polaznu pretpostavku P4: sadržaji o lobiranju u kojima se lobiranje analizira $u$ 
DRUŠ. ISTRAŽ. ZAGREB GOD. 21 (2012), BR. 2 (116)

STR. 545-567

SINČIĆ ĆORIĆ, D. VUKOVIĆ, I.: ANALIZA TISKOVNIH... poslownom kontekstu dominantno su pozitivno intonirani, jer negativni koeficijent neravnoteže upućuje na to da je sadržaj o lobiranju neravnomjerno intoniran, to jest da su prisutniji negativno intonirani sadržaji. Ovaj zaključak, iako suprotan od početne ideje autora, ne iznenađuje, jer je hrvatska poslovna praksa opterećena negativnim konotacijama privatizacije, gospodarskim kriminalom i korupcijom, a analiza objava pokazala je da se uz to često spominju pojmovi poput "lobiranja" ili "lobija". Upravo negativne konotacije lobiranja predstavljaju jedan on najvećih izazova za struku. Jedan od načina da se ovakve percepcije javnosti promijene jest etično i transparentno lobiranje, za što su odgovorni sami lobisti.

Nalazima je potkrijepljena polazna pretpostavka P5: sadržaji o lobiranju u kojima se lobiranje analizira u političkom kontekstu dominantno su negativno intonirani, jer su prisutniji negativno intonirani sadržaji. Jedan od vjerojatnih uzroka situacijske je prirode. Činjenica je da se u vrijeme objava sadržaja koji su analizirani dogodila međunarodna političko-lobistička afera, što je rezultiralo određenim brojem tekstova posvećenih upravo toj temi. Navedeno potvrđuje koliko je ugled lobiranja kao struke osjetljiv, odnosno u kojoj mjeri negativna iskustva mogu umanjiti njegovu važnost i dovesti ga u pitanje.

Udio sadržaja u kojima se lobiranje analizira u kontekstu pristupanja Europskoj uniji ili je na bilo koji način povezano s pojmom ili aktivnostima vezanima uz Europsku uniju u ukupnom broju tekstova relativno je malen te ravnomjerno pozitivno i neutralno intoniran. Navedeni zaključak je neočekivan, jer je proces pristupanja Hrvatske Europskoj uniji dugo prisutna tema u političkom i gospodarskom životu, pa bi bilo očekivano da će spominjanje lobiranja u tom kontekstu biti prisutnije. Vjerojatan razlog jest nepovezivanje lobiranja s političkim procesom pristupanja Hrvatske Europskoj uniji u očima novinara. Na temelju navedenoga, polazna pretpostavka P6: sadržaji o lobiranju u kojima se lobiranje kao pojam povezuje s pojmom "Europska unija" dominantno su pozitivno intonirani ne može se potvrditi. Kako je lobiranje izrazito prisutno u Bruxellesu, centru europskog odlučivanja, valja pretpostaviti da će se ono ubuduće češće primjenjivati, prije svega u poslovne svrhe hrvatskih poduzeća, te će se i češce opisivati pridjevima poput "poslovno" i "europsko".

\section{ZAKLJUČAK}

Iako se $\mathrm{u}$ javnosti lobističke aktivnosti na razini industrije ili specifičnog poduzeća rijetko prepoznaju, lobisti i njihova djelatnost medijski su zanimljivi, čemu govori u prilog povećanje broja medijskih sadržaja o lobiranju. S obzirom na navedeno, kao i na ranu fazu djelovanja u Hrvatskoj, lobiranje je za sada rijedak, ali svakako zanimljiv, predmet teorijskih i empirijskih istraživanja u Hrvatskoj. 
DRUŠ. ISTRAŽ. ZAGREB GOD. 21 (2012), BR. 2 (116)

STR. 545-567

SINČIĆ ĆORIĆ, D., VUKOVIĆ, I.: ANALIZA TISKOVNIH...
Analiza medijskih objava o lobiranju u Republici Hrvatskoj, provedena za potrebe rada, pokazala je da je lobiranje sve češći sadržaj novinskih članaka i objava na internetskim portalima. Iako je velik dio objava pozitivno intoniran i predočuje lobiranje u kontekstu koji razjašnjava nejasnoće oko definiranja pojma ili obuhvata struke, još uvijek su kod novinara prisutne određene nejasnoće. Navedeno ne treba čuditi, jer ni teorijska razmatranja nisu rezultirala jedinstvenom definicijom lobiranja, nego se lobiranje definira uvjetovano specifičnostima situacije (područja).

Valja očekivati da će interes za teorijsko i empirijsko izučavanje lobiranja, kao i za njegovu praktičnu primjenu rasti. Jednako tako, može se očekivati da će nove spoznaje i primjeri prakse pridonijeti boljem shvaćanju lobiranja u stručnoj i općoj javnosti.

\section{BILJEŠKE}

1 Budak (2006., 75) navodi kako za Hrvatsku postoji relativno visoka percepcija prisutnosti korupcije. Prema jednom od najviše korištenih pokazatelja, indeksu percepcije korupcije CPI Transparency Internationala, godišnji CPI za Hrvatsku i pripadajuće mjesto na svjetskoj rang-listi jasno pokazuju negativna kretanja razine korupcije $\mathrm{u}$ Hrvatskoj. Prema rezultatima istraživanja o percepciji korupcije u Hrvatskoj u 2010. godini, koje je predstavilo Ministarstvo pravosuđa, situacija se ne poboljšava. Stoviše, percepcija korupcije državnih službenika dvostruko se povećala od 2004. do 2010. godine (http://www. slobodnaevropa.org/content/hrvatska_i_percepcija_korupcije_pada _povjerenje_u_crkvu_raste_u_medije $\overline{2} \mathbf{3} 40410 . \mathrm{html})$.

${ }^{2}$ Organizacija za ekonomsku suradnju i razvoj (OECD) u godišnjem izvješću pohvalila je Hrvatsku zato što su sami lobisti predložili donošenje zakona i aktivno sudjeluju u njegovoj izradbi. Hrvatska je, naime, jedina europska država u kojoj su lobisti pokrenuli takvu inicijativu (http://javniservis.me/2011/01/21/industrija-lobiranja/).

${ }^{3}$ Detaljan kronološki prikaz analiziranih članaka dostupan je kod autora.

4 Postoje razne interpretacije triangulacije. Primjerice, Denzin (1978., prema Patton, 2002. i http://en.wikipedia.org/wiki/Triangulation_(social_ science) navodi nekoliko opisa triangulacije: triangulacija podataka, triangulacija istraživača, triangulacija teorije i metodološka triangulacija, dok Saunders i sur. (2000.) pod triangulacijom razumijevaju provjeru nalaza upotrebom više metoda prikupljanja podataka $\mathrm{u}$ istom istraživačkom projektu i nazivaju to pristupom više metoda. Triangulacija se u radu shvaća kao primjena dvaju nezavisnih istraživača $\mathrm{u}$ analizi sadržaja, koji su samostalno i nezavisno analizirali tekstove.

5 Kolbe i Burnett (1991.) navode da koeficijent slaganja veći od 0,8 predstavlja visoku razinu pouzdanosti analize.

6 Prvi su nalazi (20 analiziranih tekstova) dani na procjenu dvama nezavisnim sucima, koji su samostalno i nezavisno od autora te nezavisno jedan od drugoga proveli analizu sadržaja i usklađenim mišljenjem verificirali nalaze istraživača. Kolbe i Burnett (1991.) iznose podatak da su u 38,3\% studija nalazi analize sadržaja provjereni mišljenjem dvaju sudaca. 30,4\% studija provjereno je mišljenjem triju ili više sudaca, dok trećina autora ne navodi broj sudaca koji su analizirali nalaze autora. 


\section{PRILOG 1}

Distribucija objavljenih sadržaja po novinama

i mjesecu, za razdoblje siječanj 2009. - lipanj 2010.

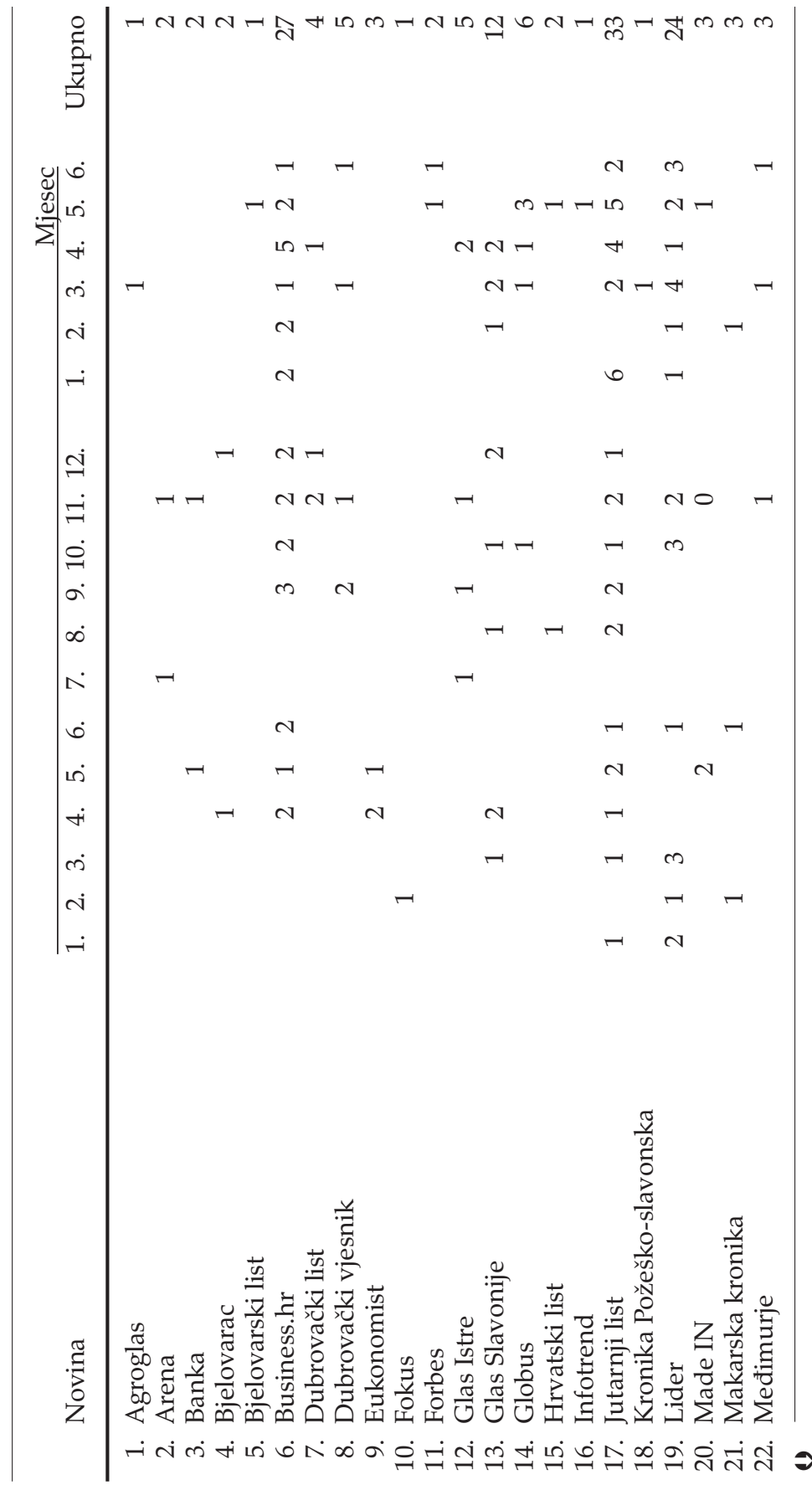




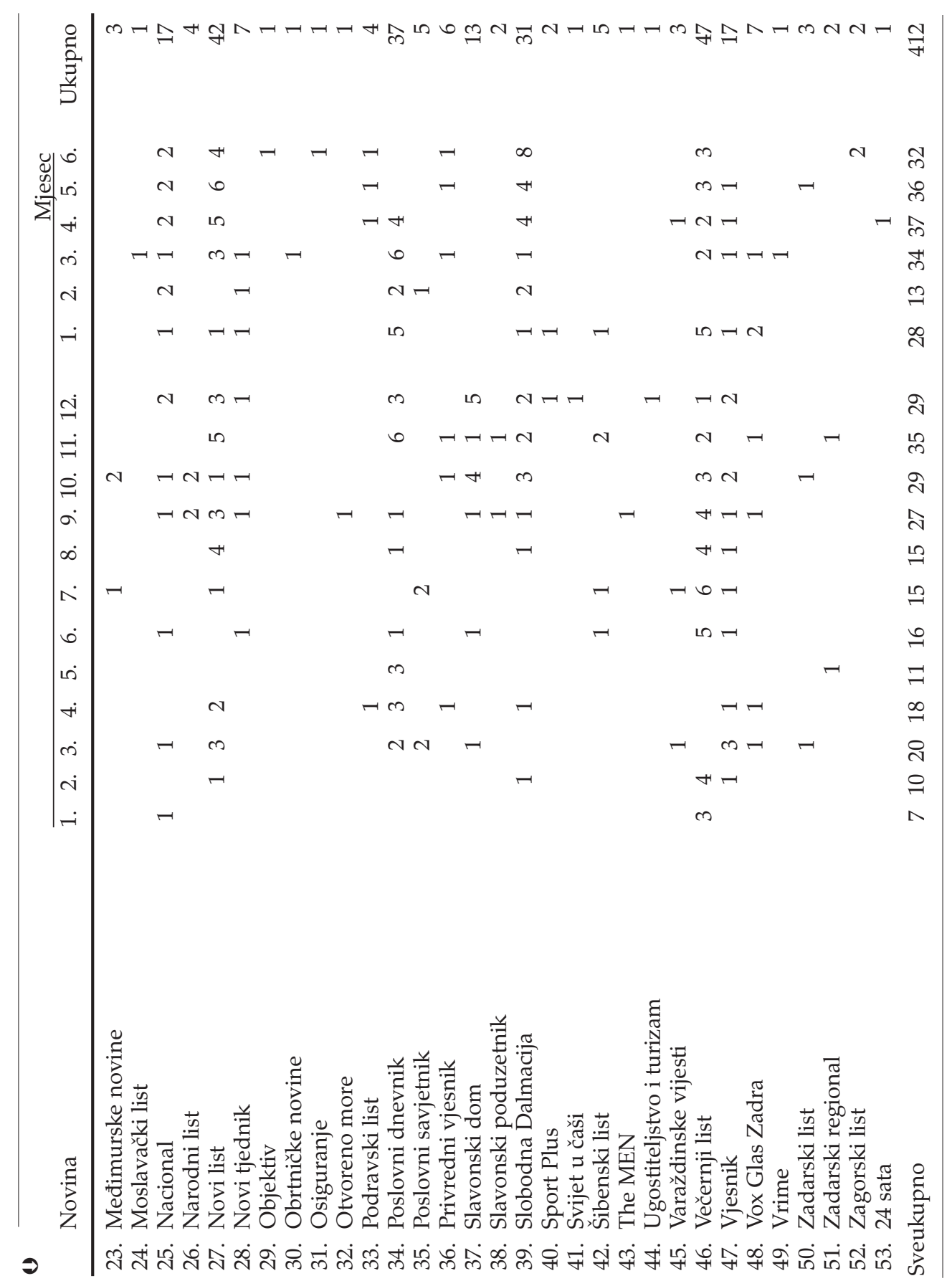




\section{PRILOG 2}

Distribucija objavljenih sadržaja po internetskom portalu i mjesecu, za razdoblje siječanj 2009. - lipanj 2010.

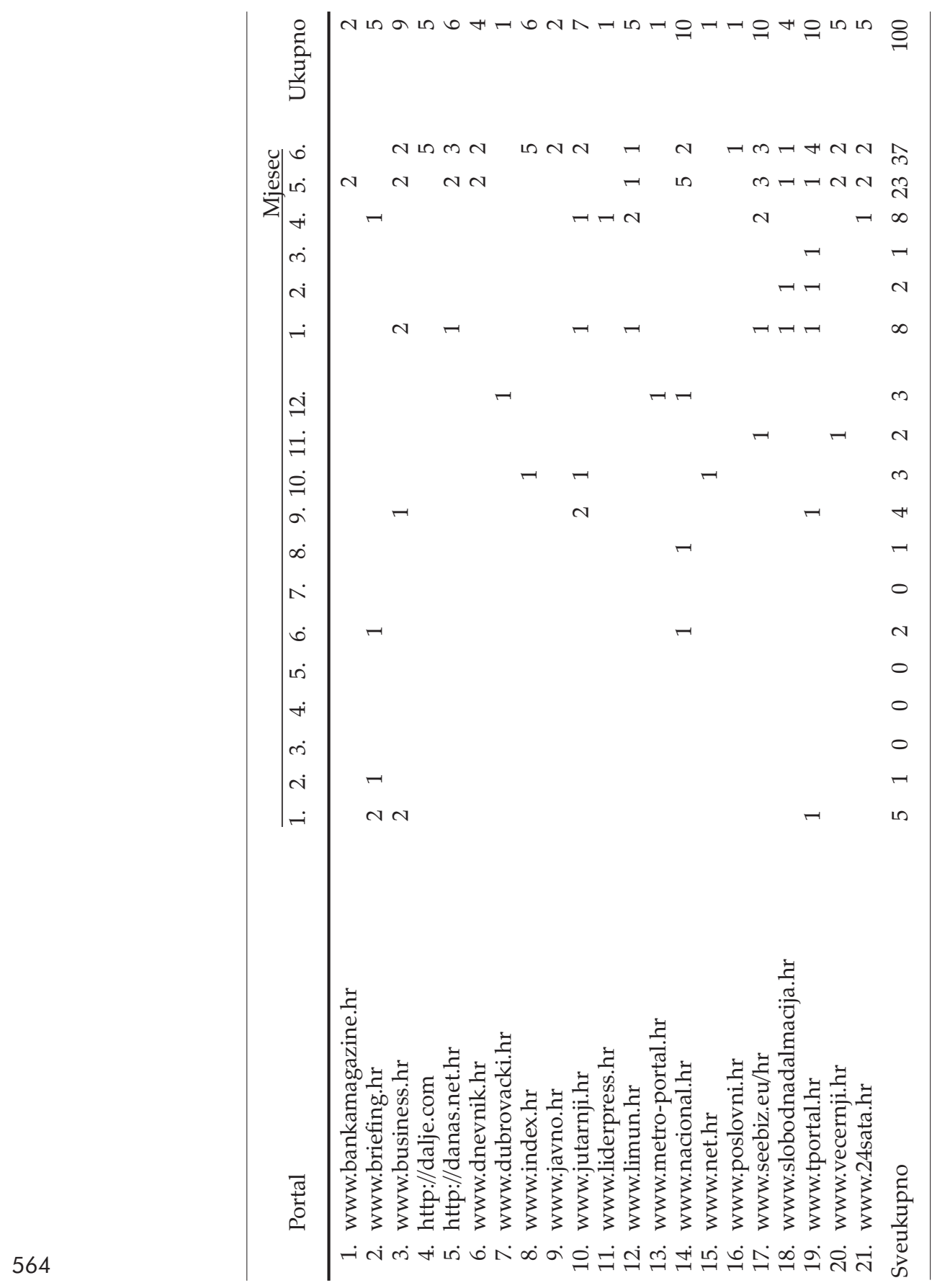


Budak, J. (2006.), Korupcija u Hrvatskoj: percepcije rastu, problemi ostaju. Privredna kretanja i ekonomska politika, 16 (106): 67-98.

Cox, T. i Mason, B. (2000.), Interest Groups and the Development of Tripartism in East Central Europe. European Journal of Industrial Relations, 6 (3): 325-347. doi:10.1177/095968010063005

Cutlip, S. M., Center, A. H. i Broom, G. M. (2003.), Odnosi s javnošću, Zagreb, Mate, Zagrebačka škola ekonomije i managementa.

De Figueiredo, J. M. i Tiller, E. H. (2001.), The Structure and Conduct of Corporate Lobbying: How Firms Lobby the Federal Communications Commission. Journal of Economics \& Management Strategy, 10 (1): 91-122. doi:10.1162/105864001300122566

European Commission, Register of Interest Representatives (2010.), https://webgate.ec.europa.eu/transparency/regrin/consultation/statistics. do (15. 12. 2010.)

European Parliament, Lobbyists Accredited to the European Parliament (2010.), http://www.europarl.europa.eu/parliament/expert/ lobbyAlphaOrderByName.do?langu (15. 12. 2010.)

Friends of the Earth Europe (2010.), How Much do the Top 50 Companies in the EU Spend?, Report, http://www.foeeurope.org/corporates/ pdf/Lobbying_in_Brussels_April2010.pdf (15. 9. 2010.)

Harris, P. i Lock, A. (1996.), Machiavellian Marketing: The Development of Corporate Lobbying in the UK. Journal of Marketing Management, 12 (4): 313-328. doi:10.1080/0267257X.1996.9964417

Harrison, S. (2000.), Shouts and Whispers: The Lobbying Campaigns for and Against Resale Price Maintenance. European Journal of Marketing, 34 (1/2): 207-222. doi:10.1108/03090560010306296

Hillman, A. J. i Hitt, M. A. (1999.), Corporate Political Strategy Formulation: A Model of Approach, Participation, and Strategy Decisions. Academy of Management Review, 24 (4): 825-842. doi:10.5465/ AMR.1999.2553256

Hogla, P. i Nilsson, S. (2006.), Lobbying Methods - An Introduction to the Matter of Lobbying, Regional Economic Development Project, Discussion paper.

IMO (2004.), Business Associations Development in Croatia, Zagreb, IMO-CIPE.

Keffer, J. M. i Hill, R. P. (1997.), An Ethical Approach to Lobbying Activities of Businesses in the United States. Journal of Business Ethics, 16 (12-13): 1371-1379. doi:10.1023/A:1005722806496

Kolbe, R. H. i Burnett, M. S. (1991.), Content-Analysis Research: An Examination of Applications with Directives for Improving Research Reliability and Objectivity. The Journal of Consumer Research, 18 (2): 243-250. doi:10.1086/209256

Krippendorff, K. (2004.), Content Analysis: An Introduction to Its Methodology, Thousand Oaks, London, New Delhi, Sage Publications, Inc. McGann, J. G. (2010.), The Global "Go-To Think Tanks": The Leading Public Policy Research Organizations In The World, http://www.sas.upenn. edu/irp/documents/2009GlobalGoToReportThinkTankIndex_1.31.20 10.02.01.pdf (1. 11. 2010.) 
DRUŠ. ISTRAŽ. ZAGREB GOD. 21 (2012) BR. 2 (116),

STR. 545-567

SINČIĆ ĆORIĆ, D., VUKOVIĆ, I.: ANALIZA TISKOVNIH...
McGrath, C. (2006.), The Ideal Lobbyist: Personal Characteristics of Effective Lobbyists. Journal of Communication Management, 10 (1): 67-79. doi:10.1108/13632540610646382

McGrath, C. (2008), The Development and Regulation of Lobbying in the New Member States of the European Union. Journal of Public Affairs, 8 (1-2): 15-32. doi:10.1002/pa.284

Milbrath, L. W. (1960.), Lobbying as a Communication Process. Public Opinion Quarterly, 24 (1): 32-53. doi:10.1086/266928

OECD Conference Centre (2009.), Self-Regulation and Regulation of the Lobbying Profession, Global Forum on Public Governance, http://www. publicgovernanceforum.org/downloads/documents/Lobbying_regu lation.pdf (2. 7. 2010.)

Patton, M. Q. (2002.), Qualitative Research \& Evaluation Methods, 3rd ed., Thousand Oaks, CA Sage Publications, Inc.

Perez-Solorzano Borragan, N. (2002.), The Impact of the EU Membership on Interest Politics in Central and Eastern Europe, http://socialsciences. exeter.ac.uk/politics/research/strategies/papers.htm (3. 6. 2008.)

Saunders, M., Lewis, Ph. i Thornhill, A. (2000.), Research Methods for Business Students, Essex, Prentice Hall.

Silverman, D. (1997.), Qualitative Research: Theory, Method and Practice, London, Sage Publications Ltd.

Tkalac Verčič, A., Sinčić Ćorić, D. i Pološki Vokić, N. (2010.), Priručnik za metodologiju istraživačkog rada: Kako osmisliti, provesti i opisati znanstveno i stručno istraživanje, Zagreb, M.E.P.

Tusinski Berg, K. (2009.), Finding Connections between Lobbying, Public Relations and Advocacy. Public Relations Journal, 3 (3): 1-19.

Veleposlanstvo Republike Hrvatske u Kraljevini Belgiji (2007.), Priopćenje 19/07, http://be.mvp.hr/?mv=499\&mh=91 (10. 6. 2010.)

Vidačak, I. (2006.), Lobiranje i kanali utjecaja interesnih skupina u proširenoj Europskoj uniji: mogućnosti i izazovi za Hrvatsku. U: K. Ott (ur.), Pridruživanje Hrvatske Europskoj uniji, Izazovi sudjelovanja, četvrti svezak (str. 81-106), Institut za javne financije i Zaklada Friedrich Ebert, Zagreb.

Vidačak, I. (2007.), Lobiranje, interesne skupine i kanali utjecaja u Europskoj uniji, Zagreb, Planetopija.

Vining, A. R., Shapiro, D. M. i Borges, B. (2005.), Building the Firm's Political (Lobbying) Strategy. Journal of Public Affairs, 5 (2): 150-175. doi:10. 1002/pa.17

Vlahović, N. (2009.), Lobiranje i nevladine organizacije. U: B. Hajoš i B. Skoko (ur.), Odnosi s javnošću za organizacije civilnog društvo (str. 101-111), HUOJ i Nacionalna zaklada za razvoj civilnog društva, Zagreb.

Vujević, M. (2000.), Uvod u znanstveni rad u području društvenih znanosti, Zagreb, Školska knjiga.

Žugaj, M. (1997.), Metodologija znanstvenoistraživačkog rada, Varaždin, Fakultet organizacije i informatike. 
DRUŠ. ISTRAŽ. ZAGREB

GOD. 21 (2012),

BR. 2 (116)

STR. 545-567

SINČIĆ ĆOORIĆ, D. VUKOVIĆ, I.:

ANALIZA TISKOVNIH.

\section{The Analysis of Print and Internet Media Content on Lobbying in Croatia}

Dubravka SINČIĆ ĆORIĆ

Faculty of Economics \& Business, Zagreb

Ivan VUKOVIĆ

Croatian Society of Lobbyists, Zagreb

The aim of the paper is to analyze media content about lobbying in Croatia, in order to point to the prevailing tone and relevance of the term "lobbying" in contemporary media content. The authors conducted quantitative content analysis of information published in daily and weekly newspapers, magazines and on Internet portals. In total, 512 pieces of content, issued in the period from 1st January 2009 until 1st July 2010 were analyzed. Only whole articles which contained in title or in body of the text the terms "lobbying", "lobbyist" and/or "lobby" were analyzed. The analysis points toward two general conclusions: (1) lobbyists and lobbying are interesting to media, which is supported by the fact that the amount of media content on lobbying is rather large and increasing through time, and (2) media contents on lobbying are different, with regards to the analysis criteria. Contents in which lobbying represents the essence of a text are dominantly positive in their tone, while contents in which lobbying is not the main term, or is just partially mentioned, are dominantly negative in their tone, regardless of the aspect of analysis, i.e. whether lobbying is analyzed from a political or business perspective.

Keywords: lobbying, content analysis, media content 